\title{
Total parenteral feeding in infants using peripheral veins
}

\author{
P. PURI, E. J. GUINEY, and BARRY O'DONNELL \\ From Our Lady's Hospital for Sick Children, Dublin, Ireland
}

\begin{abstract}
Puri, P., Guiney, E. J., and O'Donnell, B. (1975). Archives of Disease in Childhood, 50, 133. Total parenteral feeding in infants using peripheral veins. Fifteen infants with life-threatening gastrointestinal anomalies received total parenteral feeding for periods ranging from 10 to 54 days; their ages ranged from one day to 5 months. The solutions were administered through peripheral veins. All patients gained weight during the period of observation and no cases of septicaemia were encountered.
\end{abstract}

One of the most significant developments in nutrition in recent years has been the demonstration that intravenous infusion of fat, amino acids, and glucose can support normal growth and development. Certainly, this has increased the survival rate among newborns with life-threatening gastrointestinal anomalies needing early operation and prolonged postoperative intravenous therapy. Conventional methods of parenteral feeding involve the adminstration of infusate through a central venous catheter. There are certain potentially fatal hazards involved such as septicaemia and thrombosis of superior vena cava in the use of central venous catheters (Groff, 1969; Wilmore et al., 1969; Filler and Eraklis, 1970). Heird et al., (1972) reported that $75 \%$ of complications encountered with intravenous feeding were related to the central venous catheter. Maintenance of feeding via peripheral veins was difficult in the past due to the frequent occurrence of phlebitis and venous obstruction caused by the use of large volumes of hypertonic glucose in the regimen. The inclusion of Intralipid, which is isotonic and nonirritant to veins, as the major non-nitrogenous source of calories reduces the need for such large volumes of hypertonic glucose and thus eliminates the risk of osmotic diuresis and peripheral venous obstruction.

\section{Materials and methods}

During 1973, 15 infants with congenital anomalies of the gastrointestinal tract who developed complications after neonatal surgery were supported by total

Received 24 July 1974. parenteral nutrition for periods ranging from 10-54 days (Table I). Their ages ranged from one day to 5 months.

The regimen used for complete intravenous feeding is as described by Harries (1971) (Table II). The infusate consists of three basic solutions: (1) Vamin (Vitrum), composed of amino acids, fructose, and electrolytes; (2) $20 \%$ Intralipid (Vitrum), containing the fat emulsion; (3) $10 \%$ dextrose. Each nutrient solution is administered in small volumes and they are alternated with each other so that the total volume of any one solution administered is evenly distributed throughout the 24-hour period (Harries, 1971). Daily requirement of all vitamins are added to $10 \%$ dextrose solution. Each morning fluid and electrolyte requirements are determined and sodium, potassium, chloride, calcium, and magnesium concentrations further adjusted to the needs of the individual patient at the bedside. Plasma $(20 \mathrm{ml} / \mathrm{kg})$ is given once a week to provide trace elements (zinc, copper, manganese, cobalt, and iodine). Blood transfusions are given when required.

Infusion of $138 \mathrm{ml} / \mathrm{kg}$ per 24 hours provides 97 calories/kg per day, the amount necessary to meet the normal infant's need for tissue repair and growth (Borresen, Coran, and Knutrud, 1970). Calorie increases can be made by administering more fat (up to $5 \mathrm{~g} / \mathrm{kg}$ per day) and/or more $10 \%$ dextrose (Coran, 1973).

Infusate is administered via a peripheral vein using 22 gauge intravenous cannula (Argyl-Medicut) or 21-23 gauge scalp vein needle (Butterfly, Abbott). Frequent (once in 1 to 3 days) changes in drip sites are necessary to ensure adequate flow of the infused solutions. Strict aseptic technique is used in erecting intravenous drips. The entire infusion set is changed once in 24 hours. Systemic antibiotics are not used 
Infants maintain $\bar{E} d$

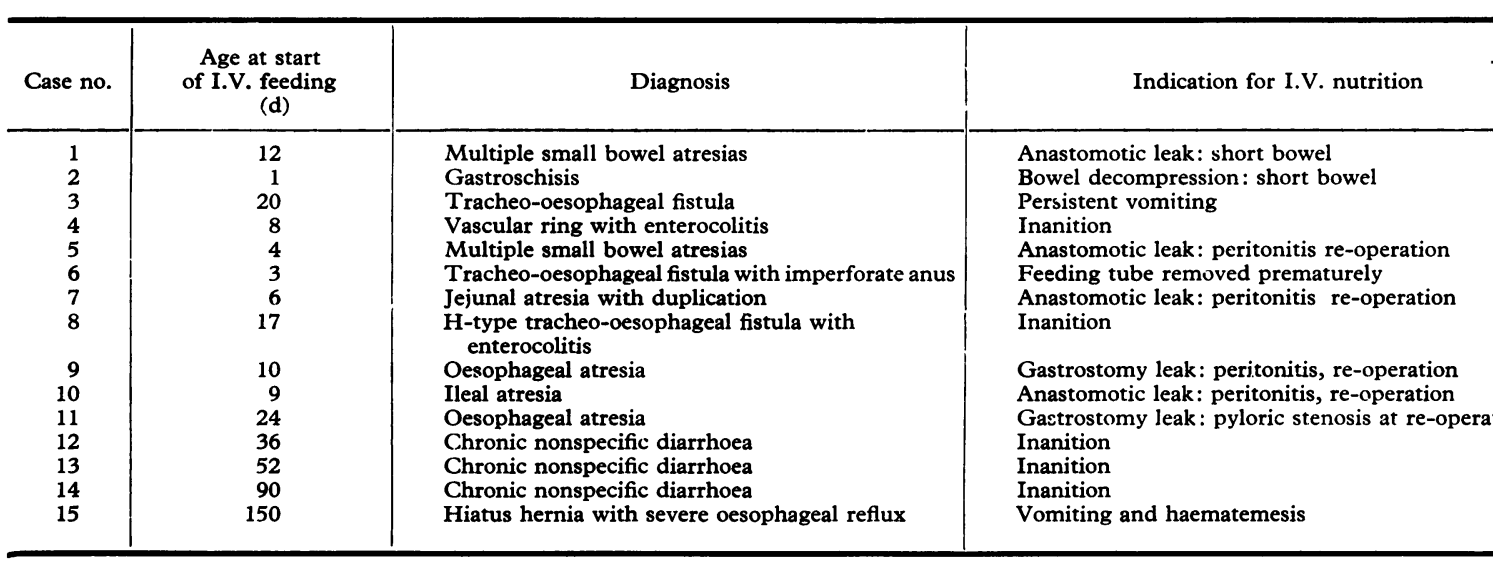

routinely unless the underlying condition necessitates their use. All patients are followed closely with daily weighing, daily intake and output chart, daily urinary sugar and specific gravity measurements, and frequent measurements of haemoglobin, blood sugar, and serum electrolytes. Liver function tests (serum bilirubin, SGOT and SGPT, and serum proteins) are checked twice a week. Daily calculations of the requirements of all nutrients are made and tabulated in the chart.

\section{Results}

Two infants died during or after the period of intravenous feeding. Case 5 died of peritonitis while on parenteral nutrition but the death appeared to be unrelated to intravenous feeding. Case 8 died of extensive bilateral bronchopneumonia a few weeks after intravenous feeding was stopped. The remaining 13 infants showed normal growth and development associated with wound healing and increased activity. All the patients showed a satisfactory weight gain. No cases of septicaemia were encountered during the period of observation. Thrombophlebitis at the needle site was not observed in any of the patients. In one patient, Case 2, extravasation of infusate resulted in sloughing of skin. Glycosuria during the initial 24 to 48 hours of intravenous feeding occurred in most infants, particularly in premature infants. Most of the babies tolerated well the volume of glucose used in the regimen and no case of osmotic diuresis with subsequent dehydration was encountered.

The following representative reports show the clinical management of these patients using intravenous feeding.

Case 1. A term male infant weighing $2.6 \mathrm{~kg}$ was born after a normal delivery. Feedings were started on the second day of life but were terminated after bile-stained vomiting. Laparotomy, performed on

TABLE II

Intravenous feeding regimen per 24 hours

\begin{tabular}{|c|c|c|c|c|c|c|c|c|}
\hline Nutrient & $\begin{array}{l}\text { Volume } \\
\text { (ml/kg) }\end{array}$ & $\underset{(\mathrm{mEq} / \mathrm{kg})}{\mathrm{Na}+}$ & $\begin{array}{c}\mathbf{K}+ \\
(\mathrm{mEq} / \mathbf{k g})\end{array}$ & $\underset{(\mathrm{mEq} / \mathrm{kg})}{\mathrm{Cl}+}$ & $\underset{(\mathrm{mEq} / \mathrm{kg})}{\mathrm{Ca}++}$ & $\underset{(\mathrm{mEq} / \mathrm{kg})}{\mathrm{Mg}++}$ & $\begin{array}{c}\text { Amino acids } \\
(\mathbf{g} / \mathbf{k g})\end{array}$ & Calories \\
\hline $\begin{array}{l}\text { Vamin } \\
20 \% \text { Intralipjd } \\
10 \% \text { Dextrose } \\
10 \% \text { Calcium gluconate } \\
\text { Potassium chloride } \\
\quad(2 \text { mEq } \mathrm{K}+\mathrm{ml}) \\
\text { Magnesium sulphate } \\
\text { Multivitamins }\end{array}$ & $\begin{array}{l}50 \\
20 \\
60 \\
3 \cdot 5 \\
1 \cdot 0 \\
0 \cdot 3 \\
3 \cdot 0\end{array}$ & $2 \cdot 5$ & $\begin{array}{l}1 \cdot 0 \\
2 \cdot 0\end{array}$ & $2 \cdot 75$ & $\begin{array}{l}0 \cdot 25 \\
1 \cdot 75\end{array}$ & $0 \cdot 15$ & $3 \cdot 5$ & $\begin{array}{l}33 \\
40 \\
24\end{array}$ \\
\hline Total & $137 \cdot 8^{\star}$ & $2 \cdot 5$ & $3 \cdot 0$ & $2 \cdot 75$ & $2 \cdot 0$ & 0.45 & $3 \cdot 5$ & 97 \\
\hline
\end{tabular}

^Total fluid volume may need to be increased using $2.5 \%$ dextrose in $0.45 \%$ saline in presence of osmotic diuresis. 


\begin{tabular}{|c|c|c|c|}
\hline $\begin{array}{l}\text { Duration of I.V. } \\
\text { nutrition } \\
\text { (d) }\end{array}$ & $\begin{array}{c}\text { Initial } \\
\text { weight } \\
\text { (kg) }\end{array}$ & $\begin{array}{c}\text { Final } \\
\text { weight } \\
(\mathbf{k g})\end{array}$ & Complications \\
\hline $\begin{array}{l}54 \\
20 \\
16 \\
10 \\
11 \\
10 \\
13 \\
18\end{array}$ & $\begin{array}{l}1 \cdot 8 \\
2 \cdot 3 \\
1 \cdot 7 \\
3 \cdot 4 \\
1 \cdot 6 \\
3 \cdot 1 \\
2 \cdot 2 \\
2 \cdot 5\end{array}$ & $\begin{array}{l}3 \cdot 0 \\
2 \cdot 7 \\
2 \cdot 5 \\
3 \cdot 7 \\
1 \cdot 8 \\
3 \cdot 3 \\
2 \cdot 7 \\
2 \cdot 9\end{array}$ & $\begin{array}{c}\text { None } \\
\text { Extravasation: sloughing of skin } R \text { ankle } \\
\text { None } \\
\text { None } \\
\text { None } \\
\text { None } \\
\text { None } \\
\text { None }\end{array}$ \\
\hline $\begin{array}{l}14 \\
13 \\
18 \\
28 \\
20 \\
16 \\
21\end{array}$ & $\begin{array}{l}2 \cdot 2 \\
3 \cdot 0 \\
2 \cdot 4 \\
2 \cdot 8 \\
2 \cdot 5 \\
2 \cdot 9 \\
3 \cdot 8\end{array}$ & $\begin{array}{l}2 \cdot 9 \\
3 \cdot 4 \\
2 \cdot 6 \\
3 \cdot 2 \\
3 \cdot 1 \\
3 \cdot 6 \\
4 \cdot 9\end{array}$ & $\begin{array}{l}\text { None } \\
\text { None } \\
\text { None } \\
\text { None } \\
\text { None } \\
\text { None } \\
\text { None }\end{array}$ \\
\hline
\end{tabular}

day 3 of life, revealed multiple atresias of small bowel with 'apple-peel' mesentery. Approximately $25 \mathrm{~cm}$ atretic intestine was resected and continuity of bowel restored by 3 end-to-end anastomoses. On the fifth postoperative day the baby developed a leak at the site of anastomosis. This was treated by nasogastric suction, intravenous fluids, and antibiotics. The baby continued to lose weight and on day 12 of life weighed only $1.8 \mathrm{~kg}$. Total parenteral nutrition was started on day 12 via peripheral veins. With the return of gastrointestinal function, small oral feeds were started on day 44 and parenteral nutrition was finally discontinued on day 54 when the baby weighed $3.0 \mathrm{~kg}$ (Fig. 1). The baby was discharged from the hospital at 10 weeks of age.

Case 2. A $2.3 \mathrm{~kg}$ premature infant with gastroschisis. Silastic sheeting was sewn to each side of the
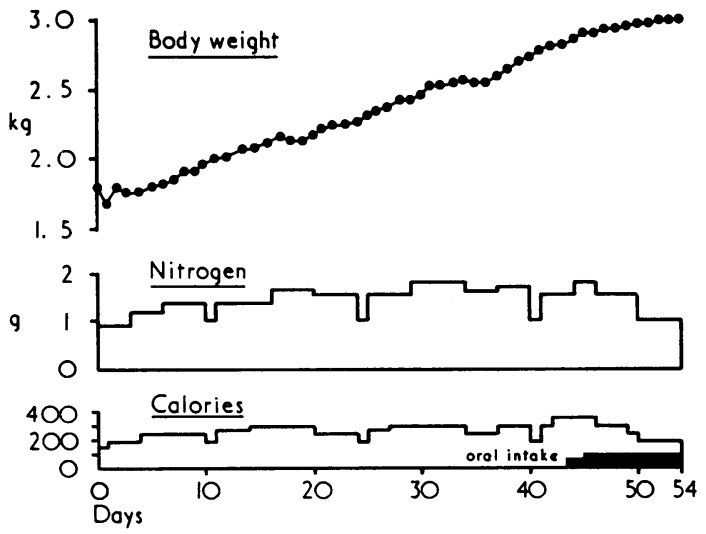

Fig. 1.-Case 1. Growth and development of a newborn during a period of intravenous feeding providing the amounts of nitrogen and the calories indicated defect and closed over the oedematous, obstructed bowel. Total intravenous feeding via peripheral veins was started on the first postoperative day. Staged closure of the defect was performed by daily plicating the silastic sheeting. On the sixth postoperative day the silastic sheet was removed and the rectus fascia and skin were closed. Small oral feeds were started on day 16 and the baby converted to total oral feeds on day 21 (Fig. 2). The patient was discharged well 62 days after operation.

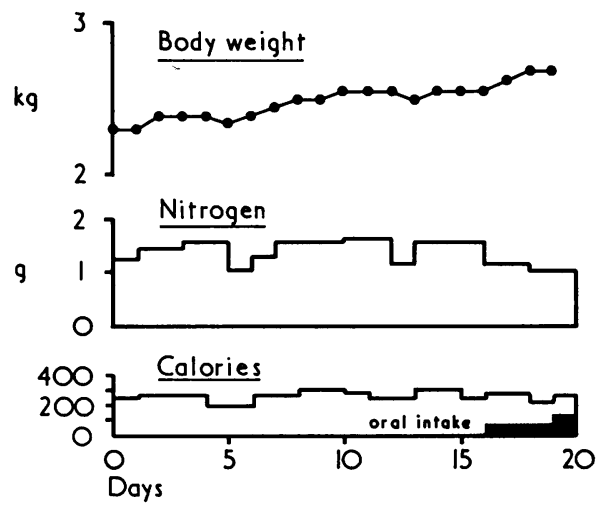

FIG. 2.-Case 2. Weight gain with associated wound healing occurred in this newborn despite two operative procedures performed on the 1st and 6th day of life. Small oral feed started on day 16 and the baby converted to total feed on day 21.

\section{Discussion}

Total intravenous nutrition is a major advance in the supportive management of infants with temporary gastrointestinal malfunction. The use 
of parenteral nutrients allows the intestinal tract to be placed completely at rest ; in addition, such nutrients appear to promote healing of the wounds. With adequate nutritional support, the infant maintains resistance to infection and withstands anaesthetic and operative stress, if further procedures are performed. This technique has saved the lives of many infants under our care who could not have survived with conventional prolonged postoperative intravenous infusions alone. The administration of intravenous feeding through peripheral veins appears to be the major advantage. The close correlation between the most serious complication of septicaemia in parenteral feeding and the central venous catheter has been emphasized by a number of investigators. No cases of septicaemia were encountered with the technique of infusing all solutions through a peripheral vein.
REFERENCES

Borresen, H. C., Coran, A. G., and Knutrud, O. (1970). Metabolic results of parenteral feeding in neonatal sugery; a balanced parenteral feeding program based on synthetic L-aminoacid solution and a commercial fat emulsion. Annuals of Surgery, 172, 291.

Coran, A. G. (1973). The long-term total intravenous feeding of infants using peripheral veins. Fournal of Pediatric Surgery, 8, 801.

Filler, R. M., and Eraklis, A. J., (1970). Care of the critically ill child: intravenous alimentation. Pediatrics, 46, 456.

Groff, D. B. (1969). Complications of intravenous hyperalimentation in newborns and infants. Fournal of Pediatric Surgery, 4, 460.

Harries, J. T. (1971). Intravenous feeding in infants. Archives of Disease in Childhood, 46, 855.

Heird, W. C., Driscoll, J. M., Schullinger, J. N., Grebin, B., and Winters, R. W., (1972). Intravenous alimentation in pediatric patients. Fournal of Pediatrics, 80, 351.

Wilmore, D. W., Groff, D. B., Bishop, H. C., and Dudrick, S. J. (1969). Total parenteral nutrition in infants with catastrophic gastrointestinal anomalies. Fournal of Pediatric Surgery, 4, 181.

Correspondence to Dr. P. Puri, Children's Research Centre, Our Lady's Hospital for Sick Children, Crumlin, Dublin 12. 